\title{
From the Archives
}

Editors' Note: Reprints of old essays will be published in some issues to make them accessible to a new generation and to track the historical development of some ideas.

Keynote presented in 2006 at the conference on proverbs held at the Obafemi Awolowo University, Ile-Ife, Nigeria.

\section{Proverbs and African Modernity: Defining an Ethics of Becoming ${ }^{1}$}

\author{
Oyekan Owomoyela \\ University of Nebraska \\ Lincoln, Nebraska
}

African proverbs have, for good reason, attracted considerable attention from scholars, both African and non-African. One notable testimony to such attention is the international conference in South Africa from which came a monumental collection of scholarly articles now available on CD and in print. Another evidence of the interest the subject has enjoyed among African scholars is the wealth of publications they have produced in recent years, for example, Adeleke Adeeko's monograph Proverbs, Textuality, and Nativism in African Literature; Ambrose Adikamkwu Monye's Proverbs in African Orature: The Aniocha-Igbo Experience; Kwesi Yankah's The Proverb in the Context of Akan Rhetoric: A Theory of Proverb Praxis; and my Yoruba Proverbs. In addition, there have been influential articles by Ayo Bamgbose, Lawrence. A. Boadi, Romanus N. Egudu, Kwame Gyekye, Yisa Yusuf, and a host of others whose omission from this rather abbreviated list is not meant as a slight.

In a recent conversation, the preeminent paremiologist, Wolfgang Mieder, called my attention to the lineup of articles in the most recent issue of Proverbium [23: 2006], in which four of the five lead articles are by Nigerian scholars (Abimbola Adesoji, Bode Agbaje, George Olusola Ajibade, and Akinola

1 Keynote presented in 2006 at a conference on proverbs held at the Obafemi Awolowo University, Ile-Ife, Nigeria. 
Akintunde Asinyanbola) and on African proverbs, an indication, he said of the present effervescence of, and future potential for, proverb studies and publications on them on African soil. Because of these efforts we now know a good deal about proverbs as a cultural resource, their functionality and the protocols for their usage, but also their artistry-structure, wordplay, imagery, and so forth, especially after calls such as Isidore Okpewho's (1992) that scholars pay due attention to the aesthetic dimensions of traditional oral forms.

\section{Making Meaningful Connections}

Shortly after receiving the invitation to speak at this forum, I had written and oral exchanges with Professor Toyin Falola who had received the announcement from the organizers. In our discussion, he reiterated the comments he had sent to them, in which he recommended that presenters be encouraged to go beyond providing proverb lists and focus more on additional intellectualization, on textuality, exegesis, and politics, for example. His words resonated with me because I believe that in Africa we have arrived at a time in history when we must revisit some questions that arose on the eve and early years of African independencies, especially those concerning literary production and studies and their "relevance." Relevance, let me remind us, referred to the utility of intellectual or artistic work in advancing the development of the newly independent countries. Although the concept of the "African personality" with its cultural dimension was a prominent and quite pertinent part of the anti-colonial rhetoric, the major preoccupation of the discourse of relevance was development, in other words the elimination of the technological and economic distance between Africa and the "developed" world. It was a preoccupation that tended to eclipse all other considerations. As an illustration, let me mention a personal anecdote. In 1963, I had a discussion with the Chief Federal Adviser on Higher Education at the time, Chief S. O. Awokoya, on an earlier commitment by the Federal Scholarship Board to extend the State Scholarship I had earned on entering the University College, Ibadan in 1959, to enable me to pursue graduate studies abroad. During the meeting, he told me that had my proposed course of study been something like Engineering he would have instructed me to go home and start preparing for departure, but since I meant to study theater he had to tell me that that subject was a luxury the country could ill afford.

The perception that such "useful" disciplines as Science and Engineering have a place in our republic while "useless" ones like Drama, Theater, or Folklore do not might have been myopic in our circumstances in the early 1960s, but not entirely incomprehensible. It has been replicated more recently even in the United States where from the 1960s to the 1980s, at least, the 
predominating pull, among the most progressive and enterprising in the academy was away from the humanities and towards the sciences, business management, and computer programming. But from the American experience also comes testimony to the deficiency of that perception. Sometime in the 1980s the country experienced a seeming epidemic of criminal behavior by corporate executives and Wall Street operatives, the best example (perhaps) being Ivan Boesky, who served twenty-two months in prison and paid \$100 million in reparation for insider trading. A cartoonist expressed the general belief that the stress on Business Education in the nation's universities and corresponding neglect of the humanities had resulted in a generation of executives indifferent to virtue or values. He depicted a frustrated and exasperated corporate executive plaintively calling to his Secretary through the intercom: "Find me somebody who knows the difference between right and wrong!" The more recent Enron debacle (which resulted in the conviction of Kenneth L. Lay and Jeffrey K. Skilling for financial malfeasance on May 25 this year) and several others indicate that the problem has not quite disappeared.

\section{The Relevance of Proverb Study}

What is the relevance of the foregoing to the present discussion? What do those instances say about why we should be interested in proverbs? What do we look to proverbs for, and what good are they in our present circumstances? I am proposing that proverbs and their study are synecdochic for the humanities, as purveyors per excellence of knowledge about the difference between right and wrong, the good and the bad, the social and the antisocial. One of the employments African scholars and writers had for proverbs in the era of decolonization was the subject of Adeleke Adeeko's publication, Proverbs, Textuality, and Nativism in African Literature. It was, as he pointed out, one of the "nativist" strategies for indigenizing African literary production and its criticism. He used the phrase "structuralist or speculative nativists" to describe those critics who conceived of any African literature that would qualify for that indigenizing qualifier as "that which has as its sources conventions and philosophies of representation derived from recognizably indigenous practices" (ix). In the chapter "My Signifier is More Native than Yours: Issues in Making a Literature African" he noted the efforts of writers like Chinua Achebe, Wole Soyinka and Ngugi wa Thiong'o, as well as critics like Chinweizu and his collaborators, who effectively "refused literary high modernism with 'indigenist' aesthetics." He also distanced himself from those African critics (like Kwame Anthony Appiah) who, as Adeeko put it, in response to "the sociology of contemporary intellectual traffic, the devastation of post-independence economies, and the ideological 
compromises that result from migration,...want to believe that those earlier defenses of 'local knowledge' are wrongheaded and claustrophobic" (26).

As Chinua Achebe acknowledged early in his career, prominent among his motivations as a writer was the desire to validate African local knowledge, Things Fall Apart (1958) being wholly dedicated to that end. Instances of such validation also abound in No Longer at Ease (1960), in those instances that highlight the cultural and psycho-social relevance of proverbs (arguably representative of traditional ethos, language, and institutions). On one occasion Obi, the main character who had recently returned from studying English in Great Britain, laments his loss of facility in his own language as he admires the local Umuofians "who made a great art of conversation[,]...men and women and children who knew how to live" (57). A little later, in a rehearsed appeal to the Union to defer his repayment of their loan to him, he makes a creditable effort at eloquent, proverb-laden Igbo. But very quickly "the speech which had started off one hundred percent in Ibo [became] fifty-fifty" (93).

The sojourn in England, in the course of which he experienced "a longing to return home [which] took on the sharpness of physical pain," did more than rob him of his native competence in the use of Igbo rhetorical resources, but it also had other devastating effects on him. When shortly after assuming his civil service duties he is arrested and charged with the crime of petty bribery, the elders of the Umuofia community in Lagos attributed his fall to his alienation from his roots and self-distancing from his people (6-7).

Young Africans who found themselves in positions analogous to Obi's on his first arrival in England, at least before our world became captive to "the sociology of contemporary intellectual traffic [and] the devastation of post-independence economies," adopted certain strategies to deal with the pain of separation from home and culture. My own first foray into collecting proverbs was a part of my strategy to manage the nostalgia I experienced when I first arrived in Los Angeles for graduate study in 1964. It has since evolved to encompass more significant uses, especially the correction of the sort of alienation the Lagos-based Umuofians blamed for Obi's loss of a moral compass, and the restoration or reinforcement of our ability to tell the difference between right and wrong.

What I envisage for African paremiologists is therefore something quite different from mere antiquarianism or traditionalism. I envisage something other than slumming explorations of aspects of the African past and culture, perhaps for amusement at the contemplation of quaint ways of being whose antics we can laugh at while congratulating ourselves for how far we have advanced beyond the unenlightened and sometimes depraved state they depict. We are wont, after all, to stress that proverbs play an important role in impressing the approved cultural and social values upon members of the 
community, in pressuring them to abide by these, and in reprimanding them for any lapses. We testify that they are preeminently well placed to perform those services because we hold them to collectively constitute a reference library of authority on the good and meaningful life. As such, therefore, they deserve our special attention in our post-colonial present, because the effects of colonialist indoctrination and the colonial education to which we were subjected persist even today. They are evident in the little we know with any certainty about our traditional past, and in our tendency to deride the past for what we take to be its flaws.

\section{The Imperative of Discernment}

In an earlier work, I took issue with the Ghanaian philosopher Kwasi Wiredu for the foregoing reason, when he cited proverbs as an obstacle in the way of African advancement in the new dispensation. For him proverbs exemplify the "authoritarian odour" that fouls African cultures, in which mandatory obedience to elders suffocates initiative on the part of the young and independence of thought on the part of mature people. His bolster for this astounding claim is "the abundance of proverbs enjoining regard for age and a dearth of proverbs advocating original and independent thinking" (1980:4). Sometime after that claim he reiterated it by contrasting African and Western approaches to managing the universe: the Western approach is to debate, clarify and modify opinions, he said, whereas the African simply relies on what has been handed down to him, saying, "This is what our ancestors said" (1984:157). I have offered rebuttals for these views elsewhere (Owomoyela 1996:20-23) and will not dwell on them in this forum, except to remark that those of us who study proverbs, African or non-African, are aware that numerous sayings urge initiative on the youth, along with respect for elders, which are quite compatible, and independent mindedness on older people, on whom the truth that ọnà kan kò wojà [Many paths lead to the market] is not lost.

I don't believe that those of us assembled here today, who have obviously demonstrated some drive, initiative, and independence of thought, will attribute all of it to our emancipation by the colonizers from the addling authoritarianism of traditional upbringing. I venture to say that the same is probably true of Wiredu.

Not very different from Wiredu's indictment of proverbs on the basis of their supposed "authoritarian odour" is a comment by another author on the reflection of certain proverbs on the morals of the societies in which they are current. Consider the Yoruba proverb "Bí ẹléyinkùlé à bá sùn, àa mú sùúrù ni, nítori pé, bó bá pẹ tití oorun a gbé ẹléyinkùlé lò" (If the owner of the backyard 
does not sleep one hangs on in his backyard for as long as necessary; eventually sleep carries the home owner away). Or Bi ẹ ba ń gbọ gbé e gbè è gbé e, ti a ko bá wọn gbé e, èyinkùlé olúwarẹ ni wọn yó gbé e sí (If you keep hearing "Haul it! Haul it! Haul it!" and you don't join them to haul it, it will end up in your backyard). Or the Jabo proverb "A lie in court saves the case." In all these cases, the import is somewhat morally suspect. The first urges patience on a person lurking outside a house at night, watching for the owner to fall asleep. The person is presumably up to no good. The second in effect argues that one is better off collaborating with people planning some odious enterprise, for that way one would be able to direct its adverse consequences away from oneself. The last simply encourages strategic lying, because "in the intertribal court which arbitrates in questions of war and peace ... a crime is not considered to be proved, nor is the culprit fully convicted, unless a confession has been made" (Herzog, 141).

To non-members of the cultures or societies involved, or members who are not educated in the proverb usage of their societies, such sayings are cause for worrying about the moral rectitude of the groups concerned. The proverbs would constitute damaging "facts" against which there could be no argument. But these are only instances that illustrate various other facts, among them, that proverbs are sometimes tongue-in-cheek, and that any society's body of proverbs contains and supports conflicting views, some of which are quite evidently contrary to the accepted beliefs and practices of the people. The task of proverb scholars, and the societies' competent proverb users, would be to point out to those befuddled by such proverbs as I have cited that for all their vaunted educative and regulatory duties proverbs are not by themselves sufficient as data for distilling a culture's ethos. They function along with experience, direct instruction, percepts, and so forth. Mindfulness of these cautionary details will enhance our ability to derive the best benefits from our study of these resources.

This is a good moment, I believe, for an elaboration on the examples I cited earlier from the American experience, the examples of Ivan Boeske, Kenneth Lay, and Jeffrey Skilling. I invoked them as manifestations of what might happen when the edifying and chastening influence of the humanities has been attenuated, and the ethics of materialism and greed glorified. I proposed proverbs in our modernity as an equivalent of the spirit of the humanities (as the creator of the cartoon I cited understood it). The spirit asserted itself in the American response to the errant behaviors of the men I mentioned. The legal system convicted all of them, and in the one case that has reached its final resolution imposed a stiff punishment. I propose that we dedicate our efforts as paremiologists to propagating and enthroning the edifying and chastening sanctions of proverbs, such that our home-grown 
Boeskes, and Lays, and Skillings would similarly be brought to book, not celebrated, lionized, and rewarded with the highest offices the land has to offer.

What Adeeko described as "the sociology of contemporary intellectual traffic....and the ideological compromises that result from migration" is relevant to the point I am making about the recuperative potential of proverb study in the service of rehabilitating African cultures and traditions in the face of our disillusionment with our post-independence record, the tarnish that has besmirched the concept of the African personality.

\section{Counter-Penetration and Self-Presentation}

In his 1979 Reith Lectures, Ali Mazrui defended African scholars' migration to Europe and America by pointing out the justice of their taking up teaching positions in Western universities. Teachers from the West had in the past been actively engaged in indoctrinating Africans, he said, and it was high time Africans "counter-penetrated" the Western world to return the favor (1980: 16). The project Mazrui advocated would be gravely undermined if the knowledge about Africa the scholarly migrants purveyed reinforced the uncomplimentary assumptions their Western students already harbored about Africa. I can testify to the difficulty of the project as it is from personal experience. Several years ago, one of my students included an advice to me in her end-of-semester evaluation of my course on African literatures, during which I had tried to correct some common misrepresentations of African cultural practices. The student, who had never been to Africa and was taking her first course related to the continent, advised me to "stop making excuses and accept the facts." What we say about ourselves has to be well-informed and designed to burnish, not tarnish our presence in the world.

In a recent article on differential access to connectivity in this age of the Internet and the perils that await the less fortunate societies in this regard, the Nigerian artist and scholar Olu Oguibe (2002) warned that such societies face not only the misappropriation of their cultural resources for unscrupulous circulation among the well connected, but also their gross misrepresentation in this forum where the societies will lack awareness that they are being misrepresented and will have no means of correcting the misrepresentation (175-83). An example of what may happen, a humorous one perhaps, is the fate of an Igbo proverb in the hands of a non-Igbo speaker. Ambrose Monye cites A. J. Shelton's translation of the Igbo proverb, Enwe si na ya ma ka ya ra wee noo utu in her 1971 collection as "Monkey says that when he copulates he eats in order to maintain the seed of his penis." Michael Echeruo however dismisses that as a misrepresentation, offering instead, "the monkey said that 
it knew the size of its anus before swallowing the $u t u$ fruit" (Monye 2-3). Misrepresentations are not always that harmless.

If I have sounded as though I am in fact making excuses for traditional institutions and refusing to entertain the thought that we might benefit from self-criticism, one explanation is my sensitivity to the importance of the point Oguibe made in his article. At the start of this presentation I mentioned Mieder's complimentary observation of the amount of proverb scholarship taking place in Africa and especially in Nigeria, attested to by the several articles from here in the latest issue of Proverbium. Along with his praise of the effort, though, he also observed, with some regret this time, that the articles had to be sent to him for publication instead of being published in Nigeria. He recalled the time, in the latter part of the last century, when a number of highly respected journals in the humanities and the social sciences originated from Nigeria (among other African countries), and wondered if any of them continues to be published. I know that some have persisted, and I so assured him, but I also mentioned the many obstacles to running and publishing scholarly journals in many countries, not least Nigeria.

The import of the necessity to publish in European and American journals is quite pertinent to this discussion. I do not wish to spell out the inevitable "ideological compromises," as Adeeko describes them, that often accompany dependence on foreign scholarly outlets just as much as they accompany migration and employment at foreign institutions. Speaking as someone concerned about Africa's place and image in the world, though, I am particularly interested in the unfortunate substitution of reporting to the world about our affairs for discussing them among ourselves, especially when the report is negative, and when we have little or no input into how the recipients of the report construe it or what they do with it. I am not by any means advocating that African scholarly exchanges, on proverbs or any other subject, be confined to African scholars, but rather that they should be at least as much among African scholars as with other scholars around the globe. As far as proverb scholarship is concerned that recommendation is particularly apropos, because, after all, one of the reasons for proverb use traditionally was to make delicate or sensitive communication among close people possible in public spaces. In other words, to enable people to wash dirty linen in public, yet hidden from the wrong eyes.

\section{The Search for Affinities}

Lest I leave my listeners with an impression of paranoia I will turn to a more cheerful discussion of the possibilities of the study of African proverb for our modernity. I return once again to Falola's admonition that we move 
away from compiling lists to the more profitable task of analyzing them and applying their insight to our pursuits. In his presentation at a proverbs conference in Pretoria in 1996 (later included in Proverbs: A Handbook) Mieder quotes Matti Kuusi's observation that if one could collect those proverbs known to be common to African cultures one would then be able to compare them with available collections of the numerous common Eurasian and European proverbs to determine whether the cultures of the three continents share "a common heritage of proverbs." Mieder then declared:

The time has surely come to assemble major comparative proverb collections based on the numerous previously published collections of small linguistic groups. Research teams need to work on this major task making use of computer technology. Only through such work will questions regarding the geographical distribution and commonality of African proverbs be answered. What proverbs are known throughout Africa? How old are they? Are they indigenous to that continent? How do they relate to the common stock of European proverbs that were disseminated by missionaries? The first step should be the establishment of a computer bank of all African proverbs collected thus far. While valuable individual collections and studies of African proverbs exist, a comparative analysis of all these African texts is highly desirable. (2004: 124).

He credits Ryszard Pachocinski with having taken a step in that direction with Proverbs of Africa: Human Nature in the Nigerian Oral Tradition (1966), which contains 2,600 entries. More collections of African proverbs have become available since Mieder's call, and, therefore, it is not premature to move on to the comparative stage.

But a more important goal, in my view, would be for us to determine, through the evidence of proverbs, the affinities among African peoples and cultures as a step towards removing the tendency we have of seeing difference rather than similarity. Colonialism entailed the fragmentation of peoples and cultures across the continent, and since the nominal end of the colonial era we have invested the divisions with an aura of immutability, and in many places we have fought bloody wars based on them and their claims. We have taken to heart such claims that Yorubaness, for example, is an invention of the colonizers; the people who call themselves Yoruba were supposedly a collection of non-communicating groups before the colonizers slapped them together to form a unit for administrative convenience. Witness the paper entitled "The Diaspora in the Making of the Homeland: Afro-Brazilian Religion and the Invention of 'the Yoruba," which J. Lorand Matory, Professor of Anthropology and of African American Studies at Harvard University, presented 
at the African Studies Pro-Seminar, University of Pennsylvania on 5 April 1996. The case is more easily made with regard to countries, Ghana, Kenya, Nigeria, for example. The Ewe are very different from the Asante; the Luo bear no relationship to the Kikuyu, and the Igbo are nothing like the Yoruba. Such sentiments are less likely to enhance the ability of the continent to thrive in the modern world than ones based on stressing what we have in common. For that reason I believe that a comparative study of our proverbs for bolster to our similarities is valuable enough, although it could also serve later to unearth our similarities with the peoples of other continents. Because of that conviction I have sought to contest the assertion the esteemed Chinua Achebe made some time ago about the fundamental differences between the Igbo and the Yoruba.

\section{Proverbs and Difference}

When interviewed by Kay Bonetti in 1988, Achebe contrasted what he characterized as Igbo republicanism with Yoruba monarchism, as he described it. And when Bonetti suggested that the difference probably explained the greater success of Christianity among the Igbo than among the Yoruba, Achebe accepted the reasoning as only partially correct. More responsible, in his words, was "the openness of the Igbo system" in contrast to that of the Yoruba. Elaborating, he argued that Igbo world view, unlike its Yoruba counterpart, was one of change, and added that a "very common saying among the Igbo is that there is nothing that is permanent in the world ... everything is changing, everything is in motion." The implication, of course, is that for the Yoruba conditions are permanent; the world is static, never changing, or as V. S. Naipaul described the African world, "finished." He went on to offer a specified example: "Look at Igbo art," he said; "it's not placid, it's not static, in the way, for instance, that [in] Yoruba art you have this composure, this sitting still and gazing placidly into the future. Igbo art is full of drama, of activity, of tension." The Igbo, he added, again in contrast to the Yoruba, did not believe that they had all the answers, and were therefore outward looking. Accordingly, seeing the power the Europeans had, the Igbo opened themselves and their society to the newcomers and their religion.

At an earlier forum I took issue with Achebess contentions with regard to both the nature of the Yoruba world view and its supposed fundamental difference from that of the Igbo. I argued then that Achebess proverb usage significantly undermined his thesis, as indeed does what we know of Igbo proverbs in general. I mean by that statement that a large number of the proverbs in Achebess fiction as well as in the Igbo repertoire as a whole, are 
either direct translations of Yoruba sayings or strikingly close to them. Take for example the following passages from Achebe's fiction:

1. "As the elders said, if a child washes his hands he could eat with kings" (TFA, 1966: 6).

2. "The lizard that jumps from the high ìrókò tree to the ground said he would praise himself if no one else did" (TFA: 16).

3. "We have a saying that if you want to eat a toad you should look for a fat and juicy one" (NLAE, 1994: 6-7).

4. "Our fathers ... have a saying about the danger of living apart. They say it is the curse of the snake. If all snakes lived together in one place, who would approach them? But they live every one unto himself and so fall easy prey to man" (NLAE: 92-93).

5. "... it was true what the Ibos say, that when a coward sees a man he can beat he becomes hungry for a fight" (NLAE: 156).

6. "A man who knows that his anus is small does not swallow an udala seed" (AOG, 1977: 71).

7. "Whenever my people go to console a woman whose baby has died at birth or soon after, they always tell her to dry her eyes because it is better the water is spilled than the pot broken" (MOP, 1989: 28).

8. "It was strange perhaps that a man who had so much on his mind should find time to pay attention to these small, inconsequential things; it was like the man in the proverb who was carrying the carcass of an elephant on his head and searching with his toes for a grasshopper" (MOP: 72).

9. Odili describes the corrupt regime in A Man of the People as "a regime which inspired the common saying that a man could only be sure of what he has put away safely in his gut or, in language even more suited to the times: 'you chop, me self I chop, palaver finish ..." (MOP 149). Most people conversant with Yoruba proverbs will, without fail, see an uncanny resemblance between the forgoing and the following Yoruba proverbs, in order corresponding to the above:

1. Omo tó mo ôwọọ wẹ á bá àgbà jẹ.

2. Alángbá tó já látorí irókò ....

3. Eni bá máa jọpọ̣lọ, a jẹ èyí tó léyin.

4. Ànikàn rìn ejò là $n$ ń fàdá pa á.

5. Eni a lè mú là nn lèdí mó.

6. Bí àjànàkú ò gbẹkệlé fùrọ, kì í mi eyin.

7. Omi ló dànù, agbè ò fọ́. 
8. A ki í ru erin lérí ká máa fi ẹsẹ wa irẹ nílè.

9. Ojọ́ a rí kéré ká jẹ kéré; ojọ́ a rí wọmù ká jẹ wọmù; àgbà ki i șubú yẹgẹ ká dà tikuùn sílẹ. Ohun a bá jẹ ní báni lọ. AND Jẹ kín jẹ kì í payò.

In addition to the foregoing I have selected some proverbs from The Book of Igbo Proverbs, a pamphlet by F. Chidozie Ogbalu, undated but most probably printed in 1955. (I have chosen this particular collection because it could not have used Achebe's fiction as a source.) These too echo Yoruba proverbs as I will show. For each proverb in his pamphlet the author gives the Igbo original and the English "meaning," his word. The "meaning" was however not always a translation of the Igbo, but more often an English popular saying with the same import. For example, for the Igbo Nracha nrache ekwegh nwanyi gba afo onu he offers the English meaning, "Procrastination is the thief of time." Here now are my selection (only their English "meanings"), with their Yoruba "relatives" appended:

1. When people get weakened ... others probably weaker would challenge them. (Bí iyà ńlá bá gbéni sánlè, kékeré a máa gorí ẹni.)

2. Too much talking leads to evil words. (Eni bá sọ púpọa a și sọ, or possibly Ờrọ púpọ, irọ́ níi mú wá.)

3. People are more disposed to fight if they knew that they would win. (Eni a lè mú là ń lèdí mọ.)

4. It is not good for people to reveal all that they know. (Inú ẹni lorúkọ tía máa so ọmo ẹni ń gbé.)

5 Everybody must bear his own burden. (Olọmú dá ọmú iyá è gbé.)

6. Helpless people are prone to be cheated always. (Bí aya olè bá dàgbà, olówó ní ń gbé e, or possibly A gbọ peé ejọ ọmọdé jàre ná, șùgbộn ta ni yó bá a wí?)

7. No place is sweeter than home. (Ilé làbọ sinmi oko.)

8. It is not good hurrying over things that need no hurry. (A kì ífi ikánjú lá obẹgbígbóná.)

9. Once a time or one at a time. (Ợkộ̣kan là ń yọsẹ lábàtà.)

10. One bad apple corrupts the others. (Erú kan ní múni bú igba ẹrú.)

The closeness between the proverbs in this group and their Yoruba equivalents, it is easy to see, is not quite as much as the closeness between Achebe's proverbs and the Yoruba versions. The correspondence in the latter case can 
be explained in one of two ways: one, that they are proverbs that grew independently out of Igbo experience and found their way into his fiction, or, two, that Achebe borrowed them from his exposure to Yoruba culture and proverbs. My belief, for reasons I have argued in the forum I referred to earlier, is that the latter is the case. But regardless of my belief in that regard, the inference we can draw from the similarity is obvious. If the proverbs I have cited from Achebe's fiction are appropriated from the Yoruba corpus, then the appropriation constitutes a tacit acknowledgement of a convergence of minds between the two peoples, a similarity of world views. If on the other hand they are original Igbo proverbs, as I believe the Ogbalu selections are, then they are an eloquent demonstration of like-mindedness between the two ethnic groups.

Although I stand by my contention that Achebe benefited from his long residence in the Yoruba part of Nigeria and exposure to Yoruba proverbs in his creative ventures, the conclusion one can draw from my Ogbalu selections is more important for my present purpose, inasmuch as they testify to the not so unexpected fact that the Yoruba and the Igbo actually think alike, at least as far as the subjects or propositions the proverbs address are concerned, even if they ate lexically and syntactically different. Of course the Yoruba and the Igbo are distinct ethnic groups with important distinguishing characteristics, beliefs, practices, and so forth. But two siblings who share the same set of parents are also distinct individuals, with important distinguishing traits, ideas, and habits. We may seek to seek out and maximize the differences in either case, or concentrate on the commonalities as relational bases. The latter option, I believe, is better conducive to collaboration in the project of building the sort of society and future I think we all desire.

\section{Conclusion}

In conclusion, let me reiterate that I am suggesting that we direct our study of African proverbs towards certain ends. Our efforts should be free of all suggestions of traditionalism or antiquarianism, marketable curiosity about exotic practices, and free of any uncomplimentary associations that "nativism" might carry. Our scholarship must be part of the effort to recuperate the best aspects of the African personality, which in turn will keep us always mindful of the difference between right and wrong, and which will, in addition, have a positive impact on our present, and on our presence in the world. Although Mazrui represented the African presence in the Western classroom as something of a payback, we should not let his humor obscure his real message, which is that we use that privileged position to better educate the West about ourselves, to the benefit of both our hosts and ourselves. 
Finally, I will cite the Yoruba proverb Ilé la ti ń késọoọ ròde (It is from the home that one dons one's fineries before venturing outdoors), which I am certain has parallels in all African cultures, and which has the English equivalent, "Charity begins at home." I invoke it to introduce the final goal I am recommending. The evidence of the proverbs I have cited from different cultures, especially those that are culturally unique in lexis, syntax, and imagery, but nevertheless express sentiments that transcend cultural boundaries, is that along with inevitable differences all cultures also have similarities. I propose that we press proverbs from our different cultures into service to illustrate and make the most of the truth that we do have much in common that we can build upon: the Akan with the Ewe; the Igbo with the Yoruba; the Luo with the Kikuyi; the Shona with the Ndebele; the Xhosa with the Zulu; any of the foregoing with any of the others; and all collectively with other peoples. That would surely be a strategy for substituting cooperation and harmonious coexistence for conflict in our African modernity.

\section{References}

Achebe, Chinua. No Longer at Ease. New York: Anchor, 1994; first published 1960.

Achebe, Chinua. "Interview with Kay Bonetti." Columbia, MO: American Audio Prose Library, n.d., Audio Tape.

Adeleke Adeeko. Proverbs, Textuality, and Nativism in African Literature. Gainesville: University of Florida Press, 1998.

Goldberg, David Theo and Ato Quayson, Eds. Relocating Postcolonialism. Oxford: Blackwell, 2002.

Herzog, George. Jabo Proverbs from Liberia: Maxims in the Life of a Native Tribe. With the Assistance of Charles G. Blooah. London: Oxford University Press for the International

Institute of African Languages and Cultures, 1936.

Matory, J. Lorand. "The Diaspora in the Making of the Homeland: Afro-Brazilian Religion and the Invention of 'the Yoruba'". Paper presented at the African Studies Pro-Seminar, University of Pennsylvania. 5 April, 1996.

Mazrui, Ali A. The African Condition: A Political Diagnosis. Cambridge: The University Press, 1980.

Mieder, Wolfgang. Proverbs: A Handbook. Westport, CT: Greenwood Press, 2004.

Monye, Ambrose Adikamkwu. Proverbs in African Orature: The Aniocha-Igbo Experience.

Lanham: University Press of America, 1996. 
Oguibe, Olu. "Connectivity and the Fate of the Unconnected." Relocating Postcolonialism. Eds.

David Theo Goldberg and Ato Quayson. Oxford: Blackwell, 2002, pp.174-83.

Ogbalu, F. Chidozie. The Book of Igbo Proverbs. Onitsha, by the Author. n.d. (1955?).

Okpewho, Isidore. African Oral Literature: Background, Character, and Continuity. Bloomington and Indianapolis: Indiana University Press, 1992.

Owomoyela, Oyekan. A Ki í: Yoruba Proscriptive and Prescriptive Proverbs. Lanham: University Press of America, 1988.

Owomoyela, Oyekan. The African Difference: Discourses on Africanity and the Relativity of Cultures. Witswatersrand: Witswatersrand University Press; New York: Peter Lang, 1996.

Owomoyela, Oyekan. "The Consequences of Subjecting Oral Texts to Modern Means of Preservation." Paper presented at the annual meeting of the International Society for Oral Literature in Africa (ISOLA) in Banjul, the Gambia, July 2004.

Owomoyela, Oyekan. Yoruba Proverbs. Lincoln and London: University of Nebraska Press, 2005.

Saayman, Willem. Embracing the Baobab Tree: The African Proverb in the 21st Century. Proceedings of the Interdisciplinary Symposium on the African Proverb in the 21st Century, University of South Africa, Pretoria, 2-7 October 1996. Pretoria: Unisa Press, 1966. Also available on CD-ROM.

Wiredu, Kwasi [J. E.]. Philosophy and an African Culture. Cambridge: The University Press, 1980.

Wiredu, J. E. [Kwasi]. "How Not to Compare African Thought with Western Thought." African Philosophy: An Introduction. Ed. Richard A. Wright. Lanham: University Press of America, 1984, pp 149-62.

Yankah, Kwesi. The Proverb in the Context of Akan Rhetoric: A Theory of Proverb Praxis. New York: Peter Lang, 1989. 